\title{
Digital Technologies and Teachers in Educational Processes: A Research in the Context of Teachers Born Before the 1980's
}

\section{Research Article}

\section{Seda GUNDUZALP ${ }^{1}$}

${ }^{1}$ Munzur University, Pertek Sakine Genç Vocational School, Tunceli, Turkey, ORCID: 0000-0003-3546-5644

To cite this article: Gunduzalp, S. (2021). Digital technologies and teachers in educational processes: A research in the context of teachers born before the 1980s, International Online Journal of Educational Sciences, 13(2), 579-591.

\begin{abstract}
ARTICLE INFO
ABSTRACT

Article History:

Being knowledgeable about the similarities and differences between the generations is especially important for school management. While digital literacy, whose importance in education cannot be

Received: 20.11.2020 ignored, is actively used by Generations Y-teachers, Baby Boomer-teachers and X teachers cannot use digital literacy with the same consistency. Baby Boomer-teachers are known to work actively in

Available online: schools. It is observed that Baby Boomer-teachers and Generation X-teachers experience difficulties 03.05.2021 in using information technologies effectively. Therefore, based on this observation, this research aims to examine the digital integration of Baby Boomer-teachers and Generation X-teachers working in the Ministry of National Education schools. The research was designed using the fundamental qualitative research of qualitative research methods. the purposive sampling method for the study is that the opinions of Baby Boomer-teachers and Generation X-teachers are needed for the aim of the research. Considering the results obtained from the study in general, it is concluded that Baby Boomer teachers and Generation $X$ teachers are trying to adapt to the needs of the digital world and making an effort to fulfill them. However, there are situations where they feel like they lack certain aspects.
\end{abstract}

(C) 2021 IOJES. All rights reserved

Keywords:

Digital Technologies, Teachers Born Before the 1980s, Generations

\section{Introduction}

The efforts of communities following different lifestyles and the people living in these communities to abide by the ever-changing and developing world have been ongoing throughout history. So much so that the personalities, perspectives, perceptions, expectations, and values of people born in different periods differ (Berkup, 2014). The age-related differences may be due to changes in technology and the social sphere during the periods when the characters of individuals are formed, war affecting social life, economic depressions, and

${ }^{1}$ Corresponding author's address: Munzur University

Telephone: +090428651351

e-mail: sedagunduzalp@munzur.edu.tr

DOI: https://doi.org/10.15345/iojes.2021.02.017 
political events. Concordantly, it can be said that the peers born and raised in the same generation may think and behave similarly (Ölçüm \& Polat, 2016).

The generation concept means the people born in similar times and share common features based on technological developments and social change, such as historical, economic, and social conditions (Hung, $\mathrm{Gu}$ \& Yim, 2008). Many studies on generations are conducted in the literature. The fact that the changes in time can be observed clearly due to the characteristics of time and the coexistence of four generations in the same working environment has led to an increase in studies on this subject. Lancaster and Stillman (2010) grouped generations as follows: 1900-1945: Silent Generation, 1946-1964: Baby Boomers, 1965-1981: Generation X, 19822000: Generation Y, 2001 and after: Generation Z. Even though debates are ongoing about the importance of the periods, there is a consensus that Baby Boomers were born after 1940 until mid-1965, Generation X was born between 1960 and 1970s, Generation Y was born from the late 1970s to mid-1990s and that Generation Z was born after these dates (Gavett, 2016). The term Traditional Generation is used for the people born before 1946 (Vardar, 2015). The time interval of the Baby Boomers that started after the end of the Second World War in 1946 and continued with the declining birth rates in the USA in 1964 is generally accepted as the years between 1946-1964 in the literature (Çemberci, Sudak, Aşçı, Öz \& Civelek, 2014; Tapscott, 2009). This generation is called Baby Boomers (approximately three million people) due to the sudden increase in the birth rates after the Second World War (Zemke, Raines \& Filipczak, 1999; Berkup, 2014; Kolnhofer-Derecskei, Reicher \& Szeghegyi, 2017). The Baby Boomers are and will be the defining generation in history (Jones, 1980). After the Second World War, a new generation called Baby Boomers emerged due to the population increase worldwide. This generation started their working life as industrial workers and transformed into the knowledge workers today. They witnessed a transformation that the previous generations did not witness and had to gain new abilities in each phase (Gündüz \& Pekçetaş, 2018). This generation, also called the war generation, is the eldest group among the working class today, and the reason why they are the smallest group today is that most of them retired due to their age. Generation X follows Baby Boomers (Yu \& Miller, 2005). The birth rate decreased approximately $15 \%$ compared to the previous years. This generation, where the unemployment rate increased, coincides with the years when the older generation worked in all occupational groups (Kolnhofer-Derecskei, Reicher \& Szeghegyi, 2017). The members of Generation X, who coincided with the technological revolution, started to use technology compulsorily. This generation is sensitive to social problems, has high business motivation and respect for authority. The fact that women start to join the workforce and want to have fewer children is important for this generation (Mengi, 2009).

Generation Y is used for people born between 1980 - 1995 (Christensen, Wilson \& Edelman, 2018). The difference between the expectations from the workplace, work performance, communication levels, and proficiency of Generation Y, which is the group that has recently started working and will work in the areas of the profession today, and the previous generation, Generation $X$, is noteworthy. The prominent element that defines Generation $Y$ is their attachment to technology. Individuals defined as Generation $Y$ have grown up using technology at every moment of their lives. This generation knows how to use technology to facilitate their work. The people born in 1995 and after are called Generation Z. Today, Baby Boomers and Generations $X, Y$, and $Z$ work alongside each other (Wiedmer, 2015). Individuals in each generation or their values or personal lifestyle characteristics, and their workplace characteristics differ. Differences among generations can affect the productivity, services, competitiveness, motivation, and the way individuals cope with change, and effective personnel management of the organizations (Bejtkovský, 2016). When the four main generations categorized by the researchers and the characteristics of the individuals related to these generations are examined, it is possible to say that the significant events that took place during their lifetime that affected the societies deeply are important determinants in identifying the generation characteristics. Understanding the characteristics of generations is essential to motivate the employees at the workplace and increase the efficiency of management. 
Educational institutions, which are at the center of change and innovation, need to minimize the differentiation between generations and thus take the lead in facilitating the adaptation of teachers to the era. In other words, the new generation education system ensures that the teachers actively participate in learning with an exploratory approach by assuming the role of guides with the interactivity provided by information technologies (Şahen-Erkan \& Balaban-Dağal, 2018). This process mostly requires teachers to temporize. Otherwise, encountering obstacles in achieving contemporary educational goals will be inevitable. Information technologies have become an important part of our lives and require a rapid integration with technology. This technological integration in the field of education and all the other fields is important. The active use of information technologies by teachers, who are the building blocks of education, will make it easier to fulfill the requirements of the era and to raise modern generations. Consequently, digital literacy concepts attract attention as concepts that need a little more attention in the field of education. Being knowledgeable about the similarities and differences between the generations is especially important for school management. While digital literacy, whose importance in education cannot be ignored, is actively used by Generations $\mathrm{Y}$ and Z-teachers, Baby Boomer-teachers and $\mathrm{X}$ teachers cannot use digital literacy with the same consistency. Baby Boomer-teachers are known to work actively in schools. It is observed that Baby Boomer-teachers and Generation X-teachers experience difficulties in using information technologies effectively. Therefore, based on this observation, this research aims to examine the digital integration of Baby Boomer-teachers and Generation X-teachers working in the Ministry of National Education schools. Answers for the following questions were sought in line with this aim:

1. What are the methods used by the Baby Boomer-teachers and Generation X-teachers to get presentations, activities, exam questions, and lesson plans?

2. Which materials are frequently used by Baby Boomer-teachers and Generation X-teachers while teaching?

3. What are the problems experienced by Baby Boomer-teachers and Generation X-teachers in adapting to the digital age?

4. What are the most difficult processes for Baby Boomer-teachers and Generation X-teachers to conduct in a computer environment?

\section{Method}

\section{Research Design}

The research was designed using the fundamental qualitative research of qualitative research methods. The aim of the fundamental qualitative method is to produce an exploratory summary of the meanings attributed to events, objects, and people through the data obtained from research participants (Sandelowski, 2000; Merriam, 2013). In the study, the digital integration compatibility of Baby Boomer-teachers and Generation X-teachers was tried to be revealed by asking their opinions on the subject in individual interviews.

\section{Research Group}

The purposive sampling technique was used for creating the research group. In the purposive sampling technique, the researchers use their judgment to identify the group of participants and select the most suitable participants for the aim of the research (Balc1, 2011). The reason for using the purposive sampling method for the study is that the opinions of Baby Boomer-teachers and Generation X-teachers are needed for the aim of the research. To identify the study group, first, the primary schools, middle schools, and high schools at the center of Elazığ Province were listed, and three schools from the educational zone in this list were chosen. The identified schools were visited to collect the age information of Baby Boomer-teachers and Generation Xteachers from the school administration. The teachers whose information was obtained and those who wanted 
to participate in the research voluntarily were selected as the working group. Fifty teachers working at the center of Elazı ğ Province and who were born between 1946 and 1964, and 1965 and 1980 were selected as the research group. The reason for choosing the schools in the city center is that generally the inexperienced teachers are first appointed mostly to districts and villages, and therefore teachers with more professional experience work in the schools in the city center.

Table 1. Frequency and Percentage Distribution Regarding the Demographic Features of the Research Group

\begin{tabular}{|c|c|c|c|c|c|}
\hline Variables & 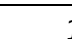 & & 2 & 3 & Total \\
\hline \multirow{3}{*}{ Gender } & & Female & Male & & \\
\hline & $\mathrm{n}$ & 12 & 38 & & 50 \\
\hline & $\%$ & 24 & 76 & & 100 \\
\hline \multirow{4}{*}{ Age } & & Baby Boomers & Generation X & & \\
\hline & & $73-55$ & $54-39$ & & \\
\hline & $\mathrm{n}$ & 17 & 33 & & 50 \\
\hline & $\%$ & 34 & 66 & & 100 \\
\hline \multirow{3}{*}{ Subject } & & Grade & Subject & & \\
\hline & $\mathrm{n}$ & 24 & 26 & & 50 \\
\hline & $\%$ & 48 & 52 & & 100 \\
\hline \multirow{3}{*}{$\begin{array}{l}\text { Educational } \\
\text { Background }\end{array}$} & & Bachelor's Degree & Master's Degree & $\mathrm{PhD}$ & \\
\hline & $\mathrm{n}$ & 39 & 8 & 3 & 50 \\
\hline & $\%$ & 78 & 16 & 6 & 100 \\
\hline
\end{tabular}

When Table 1 is examined, it can be seen that $24 \%$ of the research group was female, $76 \%$ was male, and $48 \%$ of the research group was classroom teachers, and $52 \%$ was subject teachers. When the educational background of the teachers is examined it can be seen that $78 \%$ of the teachers hold a Bachelor's degree, $16 \%$ hold a Master's degree, and 6\% hold a PhD.

\section{Data Collection}

Face-to-face interviews were conducted to determine the digital integration adaptation of Baby Boomerteachers and Generation X-teachers working in public schools. The interviews lasted approximately for 20 minutes. The "standardized open-ended interview" technique was used for the interviews (Patton, 2002; Yıldırım \& Şimşek, 2013). Before face-to-face interviews were started, the study group teachers were informed about the study and reminded that participation was voluntary. The research data were obtained using the semi-structured interview form. The interview form consisted of the questions about the presentations, exams, lesson plans of Baby Boomer-teachers and Generation X-teachers, how they get digital materials, situations that they experience difficulties in conforming to the digital age, and their evaluations about the programs that they have problems using.

A detailed literature review was conducted in the preparation process of the semi-structured interview form, and a question pool consisting of 10 questions about the subject of the research was created. Four experts were consulted about the face and content validity of the questions prepared, and accordingly, the anticipated changes were made on the form, three questions that could lead to the same answer were excluded. In addition, a pilot interview was conducted with the questions in the form; thus, the comprehensibility of the questions was tested. After all these procedures, the semi-structured interview form, consisting of seven questions, was finalized, and the questions in the form were asked to Baby Boomer-teachers and Generation X-teachers for their opinions. 


\section{Data Analysis}

The content analysis method was used to analyze and interpret the data obtained from the participants and to obtain objective and systematic results from the specific characters identified in the text. The necessary process in this analysis is to gather similar data within the framework of specific concepts and themes and to interpret the data in a way for the reader can understand (Yıldırım \& Şimşek, 2005).

In the study, firstly, the interview forms applied were collected, and the answers given to the form questions were analyzed. After the analysis, all the 50 interview forms collected from the teachers were accepted as valid. The data obtained through 50 forms were analyzed. A table consisting of a line for each question for 50 forms was created in a Word document and the answers were recorded in this table by assigning a sequence number. The data prepared in the computer environment were then analyzed using the MAxqda, a qualitative data analysis program. In the analysis of teachers' views, firstly, the themes were grouped according to the similarity of the answers given, and then the opinions were placed on the themes that were thought to be related. The frequency values for each theme and opinion were determined and presented. In addition, to provide examples for each theme, participant quotations were provided. The Baby Boomers generation participants were grouped as follows: TBB1, TBB2, TBB3... TBB17; and the Generation $\mathrm{X}$ participants were grouped as follows: TX18, TX19, TX20...

\section{The Validity and Reliability Analysis of the Study}

The data obtained after the interviews were transferred to the computer environment via a Word document, and two different encoders were asked to encode in the Maxqda program. The coders have encoded the same document independently. Later, all the coding was merged again by the researcher using the MAxqda program. Cohen's Kappa value, a statistical method measuring the consistency between two observers, was calculated for the combined documents. Two different probabilities, $\operatorname{Pr}(\mathrm{a})$ and $\operatorname{Pr}(\mathrm{e})$ are calculated when calculating the Kappa coefficient. While $\operatorname{Pr}(a)$ is the total proportion of observed fit for the two evaluators, $\operatorname{Pr}(\mathrm{e})$ is the probability that this fit will occur by chance (Cohen, 1960). According to Viera and Garrett (2005), a fit value between .81 and .99 is interpreted as a good fit. According to the Kappa value $(=0.92)$ for the study, the observers' results are consistent.

\section{Findings}

Figure 1 presents the findings obtained after analyzing the answers given by teachers to the "How do you get the presentations you use as teaching materials?" on the interview form prepared to analyze the adaptation of Baby Boomer-teachers and Generation X-teachers to digital integration.

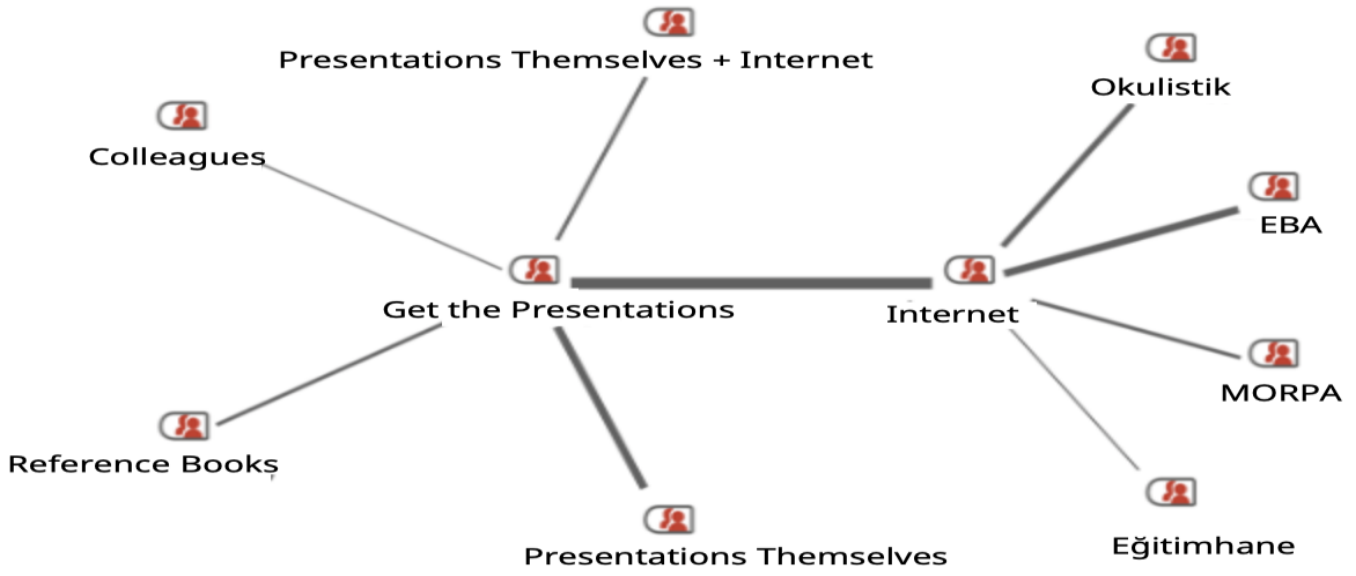

Figure 1. Teacher methods to get presentations

Baby Boomers-teachers and Generation X-teachers responded that they download and use ready-made presentations from education websites such as EBA $(\mathrm{f}=10)$, Okulistik ( $\mathrm{f}=9)$, Morpa Kampüs ( $\mathrm{f}=8)$, and 
Eğitimhane $(\mathrm{f}=5)$. In addition, teachers also stated that they prepare the presentations themselves ( $\mathrm{f}=19)$, use the presentations in reference books $(\mathrm{f}=11)$, prepare the presentations themselves using the internet $(\mathrm{f}=10)$, and take the presentations from their colleagues $(\mathrm{f}=6)$. Sample statements about the methods to get the presentations can be found below.

$\Rightarrow$ I get the presentations through applications and websites about my subject (EBA, Morpa Kampüs). (TX21)

$\Rightarrow$ I usually prepare my teaching materials. (TX19)

$\Rightarrow$ I use the internet. I get help from education programs such as Okulistik, EBA, Eğitimhane. (TX26)

$\Rightarrow$ I get presentations found on education-related websites and reference books. (TX33)

$\Rightarrow$ I get the presentations from my colleagues. (TBB1)

$\Rightarrow$ I cannot prepare presentations myself. I am not very good at using computers, I am old school. (TBB3)

$\Rightarrow$ The website called Eğitimhane is useful. I download homework and presentations from that site. (TBB10)

Figure 2 presents the findings of the answers given to one of the interview questions, "How do you get the activities (homework) you use to reinforce the lesson?"

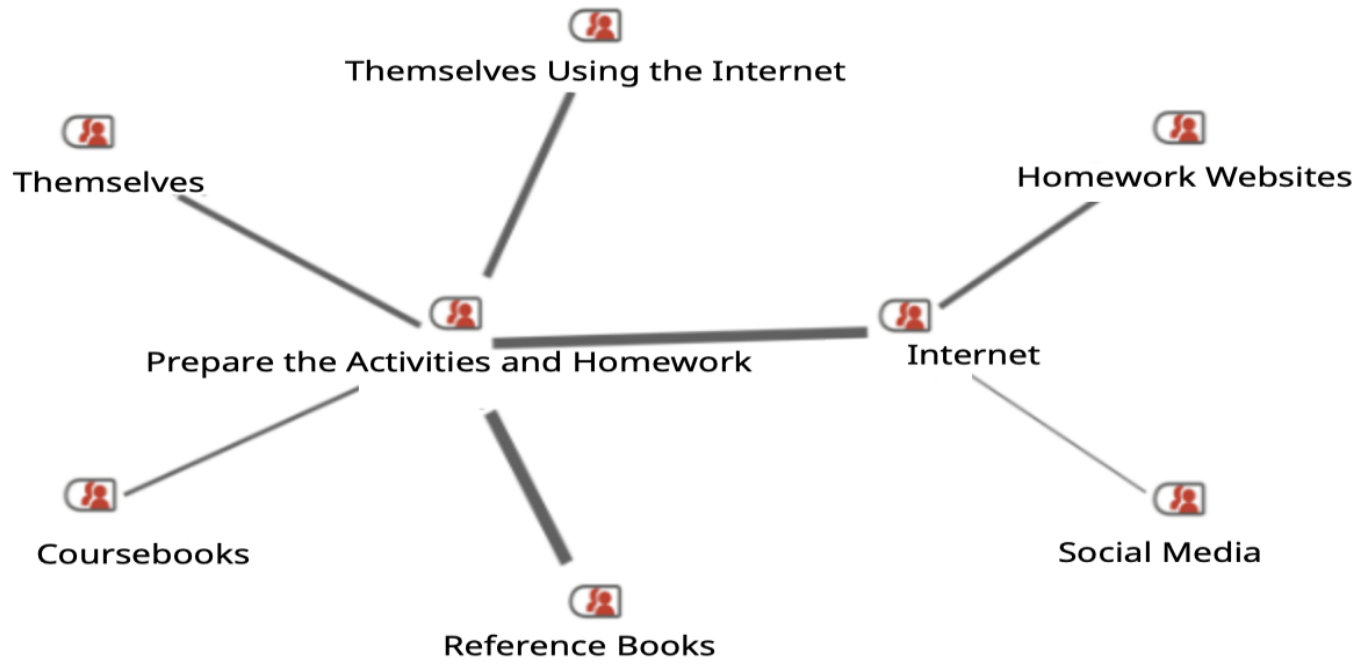

Figure 2. Teacher methods to prepare homework

Teachers stated that they frequently use reference books ( $\mathrm{f}=27)$, homework websites $(\mathrm{f}=16)$, and social media accounts $(\mathrm{f}=6)$ to get activities and homework, and several teachers also stated that they prepare the activities and homework themselves using the internet ( $\mathrm{f}=17$ ), they prepare the activities and homework themselves ( $\mathrm{f}=14)$ and take the activities and homework from coursebooks $(\mathrm{f}=11)$. Sample statements about teacher methods to prepare homework can be found below.

$\Rightarrow$ I prepare the activities myself by adapting them to the subject using the reference books. (TBB8)

$\Rightarrow$ I use different reference books, the internet, and the homework sites of different education programs. (TX23)

$\Rightarrow$ I peruse different sources. (TBB15)

$\Rightarrow$ I use reference books and the internet (Facebook, Instagram, and various educational websites. (TX34)

$\Rightarrow$ I prepare them myself. (TX48)

Figure 3 presents the findings obtained after analyzing the answers given to the question "How do you prepare your exam questions?" asked the teachers who participated in the research. 


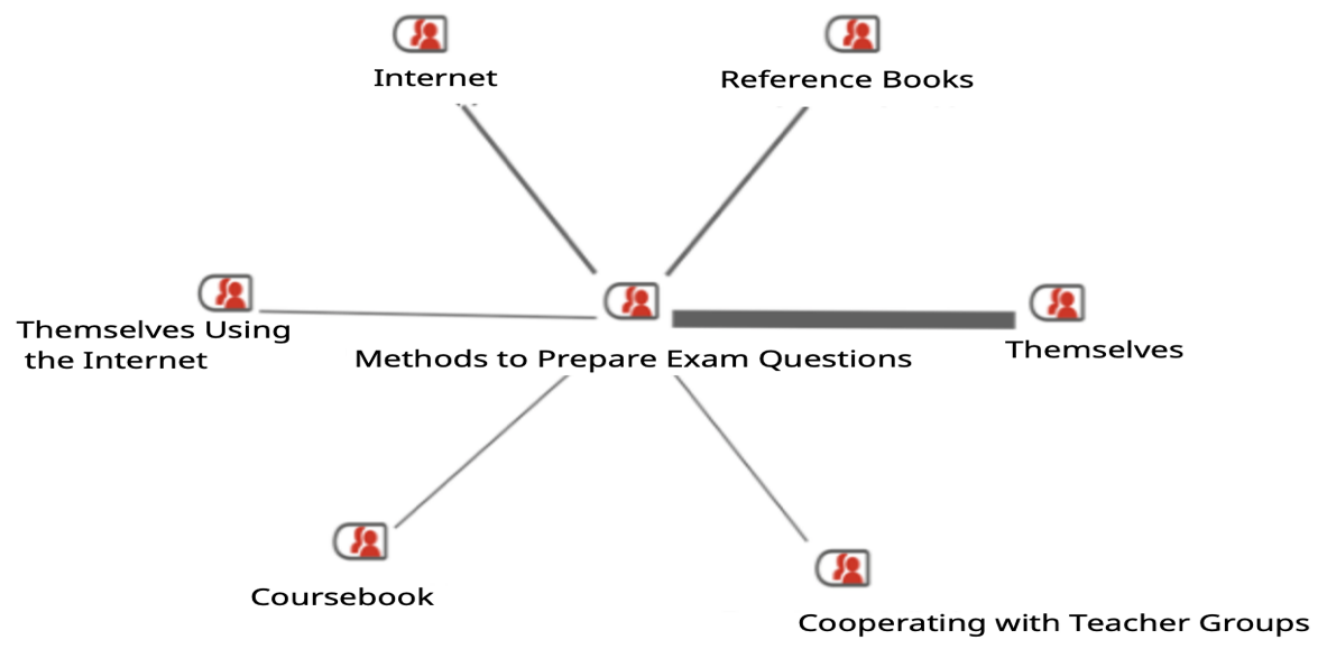

Figure 3. Teacher methods to prepare exam questions

Baby Boomer-teaches and Generation X-teachers stated that they generally prepare the exam questions themselves $(\mathrm{f}=27)$. In addition, they also stated that they prepare the exam questions themselves using the internet $(\mathrm{f}=3$ ) using the reference books $(\mathrm{f}=9)$, internet $(\mathrm{f}=8)$, coursebook $(\mathrm{f}=3)$, and by cooperating with teacher groups $(\mathrm{f}=2)$. Sample statements about teacher methods to prepare exam questions can be found below.

$\Rightarrow$ I prepare the exam questions using different references based on the learning outcomes. (TX33)

$\Rightarrow$ I compile an exam after reviewing a few exam papers. (TX38)

$\Rightarrow$ I sometimes prepare the exam questions, and sometimes I get the questions from different sharing platforms. (TX41)

$\Rightarrow$ I prepare the exam questions in accordance with the coursebook. (TX44)

$\Rightarrow$ Primarily, I ask the questions I prepared based on the learning outcomes. (T25)

$\Rightarrow$ We prepare the exam questions together with the other colleagues teaching the same class following our school level. (TBB8)

Figure 4 presents the findings obtained after analyzing the responses given to the question "How do you prepare your lesson plans?" asked the teachers who participated in the research.

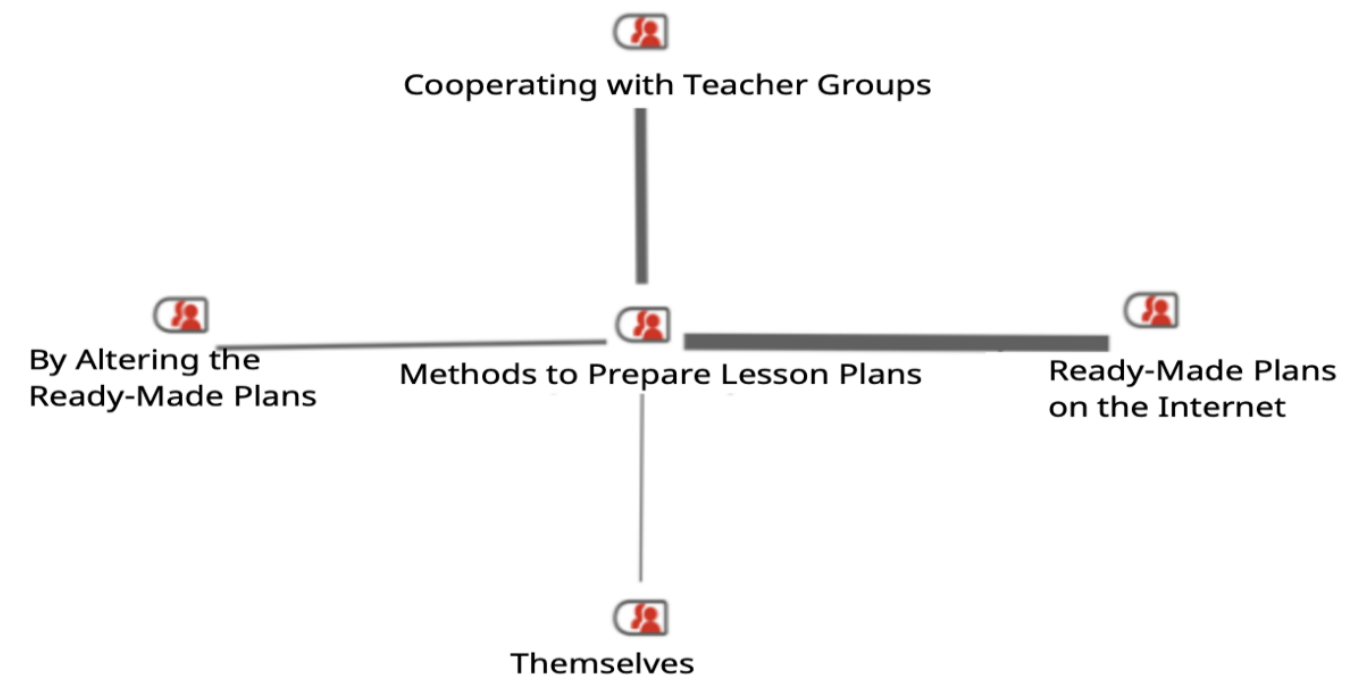

Figure 4. Teacher methods to prepare lesson plans 
Teachers stated that they prepare the lesson plans using the ready-made plans on the internet $(\mathrm{f}=17)$, by cooperating with teacher groups $(\mathrm{f}=14)$, by altering the ready-made plans $(\mathrm{f}=12)$, and themselves $(\mathrm{f}=8)$. Sample statements about teacher methods to prepare lesson plans can be found below.

$\Rightarrow$ We prepare it together with other colleagues. (TBB15)

$\Rightarrow I$ use the ready-made plans after making the necessary changes. (TX23)

$\Rightarrow$ I use the plans that I download from the internet. (TX33)

$\Rightarrow$ I use my plans that I prepare according to the class I teach. (TX41)

Figure 5 presents the findings obtained after analyzing the answers given to the question "Which digital materials do you frequently use while teaching?" asked the teachers who participated in the research.

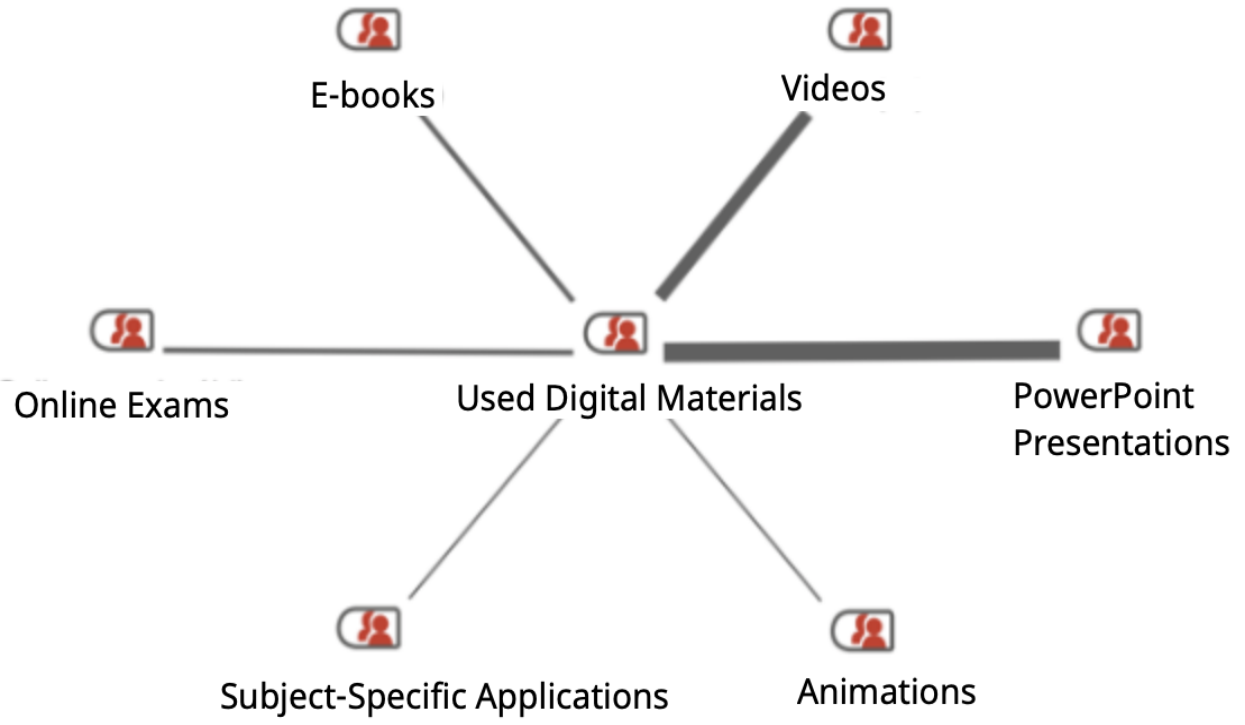

Figure 5. The frequency of teachers using digital materials

Baby Boomer-teachers and Generation X-teachers stated that they frequently use PowerPoint presentations ( $\mathrm{f}=41$ ), videos ( $\mathrm{f}=28)$, e-books $(\mathrm{f}=16)$, online exams $(\mathrm{f}=14)$, subject-specific applications $(\mathrm{f}=9)$ and animations $(\mathrm{f}=4)$ as digital materials.

Figure 6 presents the findings obtained after analyzing the answers given to the question "Please state the problems that you encounter while adapting to the digital age." asked the teachers who participated in the research.

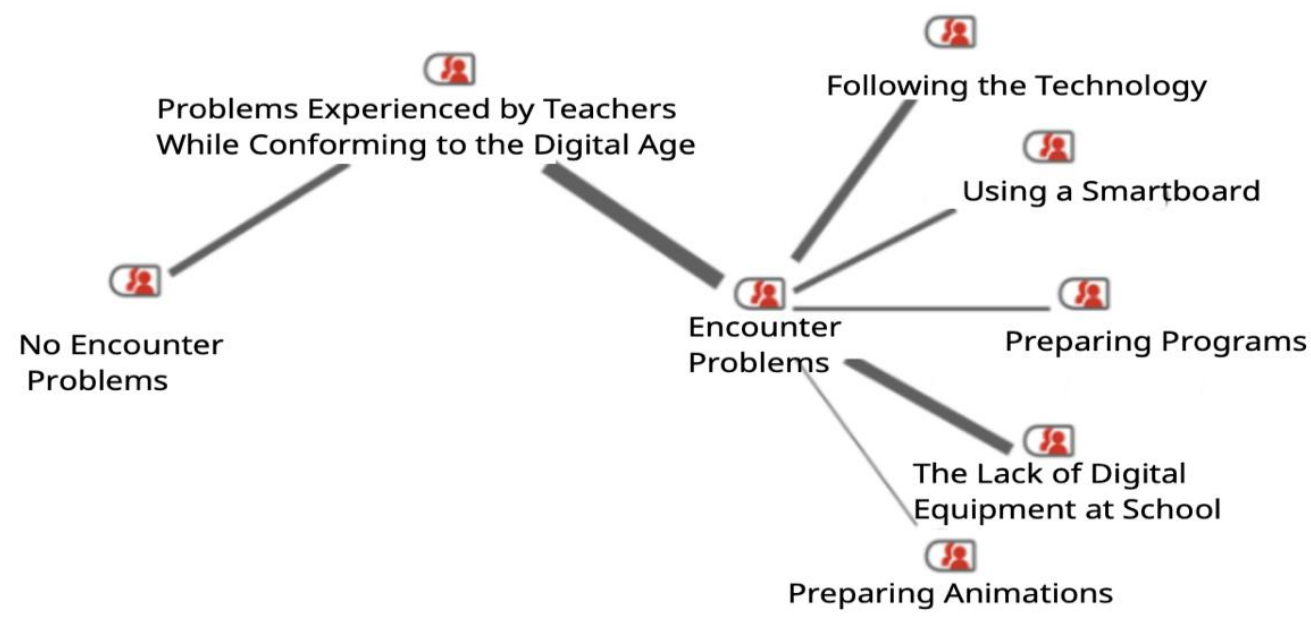

Figure 6. Problems experienced by teachers while conforming to the digital age 
Baby Boomer-teachers and Generation X-teachers stated that they encounter problems about the lack of digital equipment at school $(\mathrm{f}=21)$, following the technology $(\mathrm{f}=19)$, using a smartboard $(\mathrm{f}=9)$, preparing programs $(f=6)$, and preparing animations $(f=4)$. Sample statements about teacher methods to prepare exam questions can be found below.

$\Rightarrow$ I cannot use several applications on smartboards. It is called a smartboard, but I frequently encounter problems, sometimes due to technical reasons, or that I do not know what to do when it gives errors. (TBB17)

$\Rightarrow$ I do not encounter any problems. I know my way around a computer. It must be like that at this age. Teachers should be good at using computers and keep up with the students. (TX22)

$\Rightarrow$ I have difficulties while preparing presentations. Therefore, I generally use ready-made presentations or ask for help. (TBB3)

$\Rightarrow$ I have difficulties in keeping up with the latest trends since they change frequently. There are novelties always; something changes before I get used to it. The young are better at these issues. We are old school. We do not need to be up-to-date. I can provide the necessary education to my students using old methods as well. (TBB2)

Figure 7 presents the findings obtained after analyzing the answers given to the question "Which application is difficult for you to prepare in a computer environment?" asked the teachers who participated in the research.

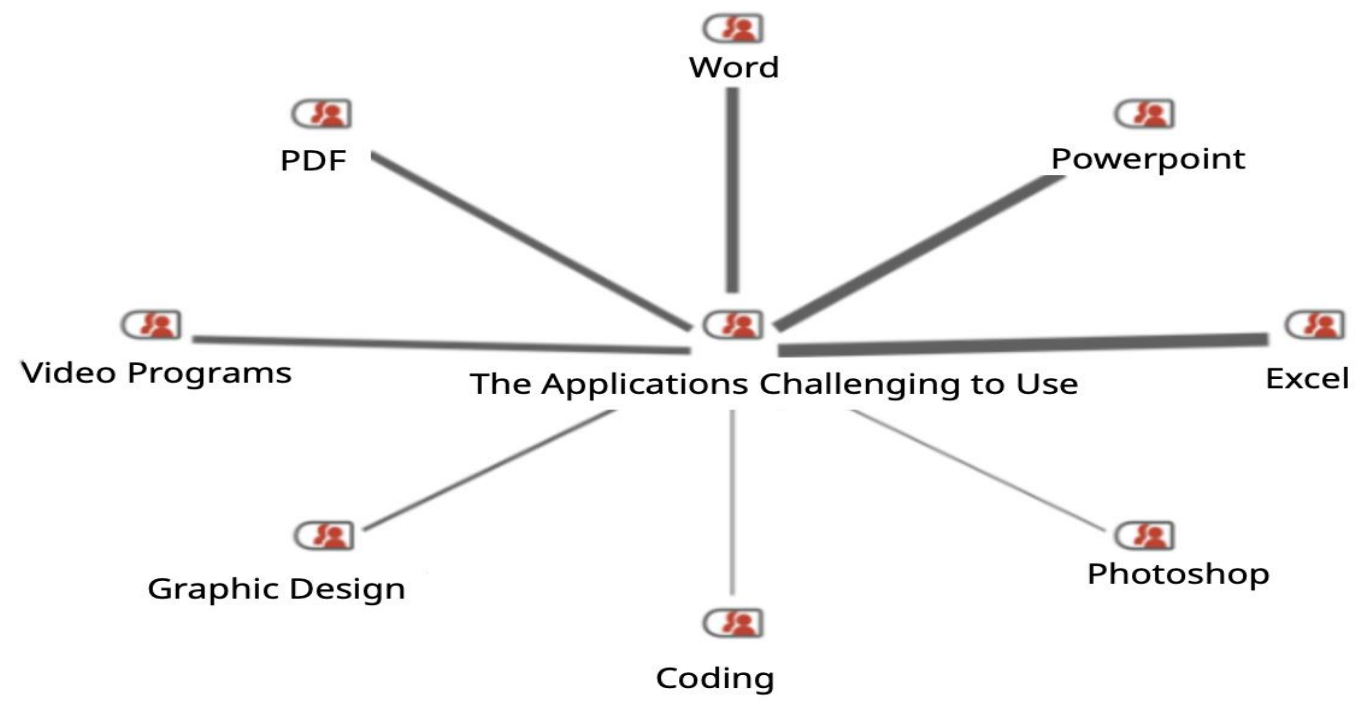

Figure 7. The computer applications that the teachers find challenging to use

Baby Boomer-teachers and Generation X-teachers stated that they have difficulties in using Excel ( $\mathrm{f}=28)$, PowerPoint $(\mathrm{f}=23)$, Word $(\mathrm{f}=21)$, video programs $(\mathrm{f}=9)$, PDF $(\mathrm{f}=8)$, graphic design $(\mathrm{f}=5)$ and coding $(\mathrm{f}=4)$.

$\Rightarrow$ I experienced difficulties using the Excel program. I had to use it several times, but one should know it in detail. I asked for help from my son. I find the programs such as Excel, PowerPoint, Word challenging to use. (TBB17).

$\Rightarrow$ We frequently use PowerPoint and Word. Sometimes I have difficulties in using these programs. The young are better at such issues. (TBB13).

\section{Results and Recommendations}

With the widespread presence of technology in our lives, the role of teachers in the digital world, which has increased visibility especially in the field of education and facilitates the teacher's work in education and training activities, the perception of this role and their competencies in performing their role have become important. Teachers have the characteristics of the generation that they are born in, and who were born in different generations, may experience difficulties in adapting to the digital world. Researching the adaptation 
of Baby Boomer-teachers and Generation X-teachers, who were born in the 1940s and 1960s, to the digital world is important since it is known that the teachers who belong to the generation in question fall behind in the following technology due to their age. Accordingly, interviews were conducted with Baby Boomerteachers and Generation X-teachers who work in the Ministry of National Education schools to determine their adaptation to digital integration, and their opinions were asked in detail. Baby Boomer-teachers and Generation X-teachers were asked questions about how they get presentations, activities, exams, plans, and digital materials, the situations in which they have difficulties in adapting to the digital age, and the programs they have difficulties in using from their own perspectives.

Baby Boomer-teachers and Generation X-teachers indicated that they download presentations, the digital materials to be used in lessons frequently available on the internet, from educational sites such as EBA, Okulistik, Morpa Campus, and Eğitimhane. In addition, several teachers prepare the presentations themselves, use the presentations in the reference books, get help from the internet while preparing the presentations, and get the presentations from their colleagues. Teachers stated that they frequently use reference books, homework websites, and social media to get activities and homework, or they prepare the activities and homework on their own, get help from the internet while preparing, and use reference books. Baby Boomer-teachers and Generation X-teachers described that they regularly prepare the exam questions by themselves. In addition, they also indicated that they prepare the exam questions using the reference books, internet, and course books, and also prepare the questions in cooperation with teacher groups. Teachers stated that they either prepare their lesson plans themselves, use the ready-made plans by making several changes, use ready-made plans, or prepare the lesson plans in cooperation with the teacher groups. The generationteachers in question stated that their frequently used digital materials are PowerPoint presentations, videos, e-books, online exams, specific applications for the subject, and animations. Baby Boomer-teachers and Generation X-teachers expressed difficulties in using Excel, PowerPoint, Word, video programs, PDF, graphic designs, and coding in a computer environment. Baby Boomer-teachers and Generation X-teachers stated the reasons for their problems in adapting to the digital age as follows: lack of hardware at schools, difficulties in following the technology, and using smart boards, preparing programs, and animations.

Howard, Raina, and Jones (2001) indicated in their study that with age, attitude towards technology and proficiency in technology use decrease. Akoyunlu (2002) determined in the study that teachers between the ages of 21-35 and who have experience between 1-15 years use the internet frequently. Eroğlu (2019) expressed that as teachers age and gain experience, their use of information technologies decreases. In another study, Cin (2018) concluded that teachers with less experience use technology more and that this situation can be explained with the fact that the young teachers who are new to the profession meet with technology at an earlier age, tend to use technology, and study how to integrate technology into education during their undergraduate education. Kocaoğlu (2015) researched the proficiency level of teachers using interactive smart boards and determined that teachers with more professional seniority have lower levels of proficiency compared to other age groups. Bal and Karademir (2013) concluded that teachers with less professional seniority think they use technology adequately. Avc1 (2014), in the thesis study conducted with science teachers, determined that teachers with less professional seniority have higher technology use levels than the teachers with more professional experience. Çakmaz (2010) identified that teachers with more professional seniority rely on traditional methods and old technologies, and teachers who are at the beginning of their profession prefer new technologies. Elçiçek (2019) detected that teachers who are between the ages of 20 and 30 use EBA more frequently than teachers who are 41 and above. Uyduran (2018) found that classroom teachers with professional seniority between 1-15 years have higher levels of information technology use, technology literacy, and integrating technology into the lesson compared to classroom teachers with 16 or more years of professional seniority; and emphasized that teachers between the ages of 26 and 40 have higher levels of using information technologies, technology literacy, and integrating technology into the lesson than 
teachers aged 41 and over. When the integration of technology is thought of as an essential factor to affect the future, as Howard and Mozejko (2015) stated, teachers are expected to try new technologies and teaching strategies and integrate these into education as technology is anticipated to develop continually. Understanding that several teachers are more open to change and taking risks, and others may be more cautious and nervous, is also important.

Considering the results obtained from the study in general, it is concluded that Baby Boomer teachers and Generation $\mathrm{X}$ teachers are trying to adapt to the needs of the digital world and making an effort to fulfill them. However, there are situations where they feel like they lack certain aspects.

The teachers are expected to adapt quickly to digital integration with the introduction of smart boards to the classrooms within the scope of the Fatih Project of the Ministry of National Education. However, the anticipation that teachers over a particular age group have difficulties during this adaptation phase coincides with the research results.

Based on the research results, it is thought that it would be beneficial to include more practical training by increasing the number of in-service training, especially for Baby Boomer-teachers and Generation Xteachers. In addition, considering the millennium students who have grown up with technology in the digital age, providing appropriate opportunities for the retirement of Baby Boomer-teachers and easier adaptation of other teachers will increase education quality.

The study group of this research was teachers, which can be considered as a limitation. Other studies to be conducted for the same subject can target school principals. Studies can also be conducted to identify the difference between the digital adaptation of teachers and school principals by asking their opinions. The research does not include comparative analysis of data obtained from the opinions of teachers from different generations. The adaptation of different generations of teachers to digitalization and the comparison of the difficulties they face may contribute to the determination of the learning needs between different generations. 


\section{REFERENCES}

Akkoyunlu, B. (2002). Öğretmenlerin internet kullanımı ve bu konudaki öğretmen görüşleri. Hacettepe Üniversitesi Ĕ̆itim Fakültesi Dergisi, 22(22).

Avc1, T. (2014). Fen bilimleri öğretmenlerinin teknolojik pedagojik alan bilgisi ve öz güven düzeylerinin belirlenmesi. (Yayımlanmamış yüksek lisans tezi). Celal Bayar Üniversitesi, Manisa.

Bal, M. S. \& Karademir, N. (2013). Sosyal bilgiler öğretmenlerinin teknolojik pedagojik alan bilgisi (TPAB) konusunda öz-değerlendirme seviyelerinin belirlenmesi. Pamukkale Üniversitesi Ĕ̆itim Fakültesi Dergisi, $34,15-32$.

Bejtkovský, J. (2016). The employees of Baby Boomers generation, generation X, generation Y and generation $\mathrm{Z}$ in selected Czech corporations as conceivers of development and competitiveness in their corporation. Journal of Competitiveness, 8(4), 105-123.

Berkup, S. B. (2014). Working with generations $X$ and $Y$ in generation $Z$ period: Management of different generations in business life. Mediterranean Journal of Social Sciences, 5(19), 218.

Christensen, S. S., Wilson, B. L., \& Edelman, L. S. (2018). Can I relate? A review and guide for nurse managers in leading generations. Journal of nursing management, 26(6), 689-695.

Cin, A. (2018). Ortaokul öğretmenlerinin teknolojik pedagojik alan bilgileri ile bilişim teknolojisi kullanım düzeylerini incelenmesi Mersin ili örneği. (Yayımlanmamış yüksek lisans tezi). Mersin Üniversitesi Eğitim Bilimleri Enstitüsü, Mersin.

Cohen, J. (1960). A coefficient of agreement for nominal scales. Educational and Psychological Measurement, 20, $37-46$.

Çakmaz, B. (2010). Okul öncesi öğretmenlerinin eğitim teknolojilerini kullanma durumlarının incelenmesi. (Yayımlanmamış yüksek lisans tezi). Abant İzzet Baysal Üniversitesi, Sosyal Bilimler Enstitüsü, Bolu.

Creswell, J. W. (2013). Qualitative inquiry \& resaerch design: Choosing among five approaches (3rd ed). New York: Sage.

Çemberci, M., Sudak, M. K., Aşçı, M. S., Öz, S. \& Civelek, M. E. (2014). Y neslinin örgüt ortamındaki davranış farklılıklarının analizi. Online Academic Journal of Information Technology, 5(15), DOI: 10.5824/13091581.2014.2.004.x.

Elçiçek, A. (2019). Ĕ̆itim bilişim ağı (EBA) web sitesinin öğretmenler tarafından kullanım sıklı̆̆ının incelenmesi: Mardin ili Kızlttepe ilçesi örneği. (Yayımlanmamış yüksek lisans tezi). Sakarya Üniversitesi Eğitim Bilimleri Enstitüsü, Sakarya.

Eroğlu, N. (2019). Lise öğretmenlerinin bilişim teknolojilerini kullanım düzeylerinin incelenmesi. (Yayımlanmamış yüksek lisans tezi). Gaziantep Üniversitesi Eğitim Bilimleri Enstitüsü, Gaziantep.

Gavett, G. (2016). Birleşik Jenerasyonlar. https://hbrturkiye.com/dergi/birlesik-jenerasyonlar. Retrieved at: 12.12.2019

Gündüz, Ş. \& Pekçetaş, T. (2018). Kuşaklar ve örgütsel sessizlik/seslilik. İşletme Bilimi Dergisi (JOBS), 6(1), 89115. DOI: $10.22139 /$ jobs.399952

Howard, P. E. N., Rainie, L., \& Jones, S. (2001). Days and nights on the internet. The impact of a diffusing technology. American Behavioral Scientist, 45(3), 383-404. 
Howard, S. K. \& Mozejko, A. (2015). Teachers: technology, change and resistance. In M. Henderson \& G. Romeo (Eds.), Teaching and Digital Technologies: Big Issues and Critical Questions (pp. 307-317). Port Melbourne, Australia: Cambridge University Press.

Hung K., F. Gu, \& Yim, C. (2008). A social instutional approach to identifying generation cohorts in China with a comparison of American consumers. Journal of International Business Studies, 38, 836-853.

Jones, L. Y. (1980). Great expectations: America and the baby boom generation. Coward, New York: McCann and Geoghegan.

Kocaoğlu, Ü.B. (2015). Lise öğretmenlerinin fatih projesi teknolojilerini kullanmaya yönelik öz yeterlik inançları: Kayseri ili örneği. (Yüksek Lisans Tezi). Sakarya Üniversitesi, Eğitim Bilimleri Enstitüsü, Sakarya.

Kolnhofer-Derecskei, A., Reicher, R. Z., \& Szeghegyi, A. (2017). The X and Y generations' characteristics comparison. Acta Polytechnica Hungarica, 14(8), 107-125.

Lancaster, L.C. \& Stillman, D. (2010). The M factor: how the millennial generation is rocking the workplace. New York: Harper Business.

Mengi, Z. (2009). Z kuşağı geliyor. (http://www.zeynepmengi.com/2012/06/z-kusagi-geliyor/) Dowlanded at: 05.08.2019.

Ölçüm, D. \& Polat, S. (2016). Evaluation of teacher image on the basis of generations. Journal of Teacher Education and Educators, 5(3), 361-391.

Patton, M. Q. (2002). Qualitative research and evaluation methods (3rd ed.). Thousand Oaks, CA: Sage.

Şahen-Erkan, S.S. \& Balaban-Dağal, A. (2018). Öğretmen adaylarının dijital okuma, yazma ve sunum hazırlama becerileri hakkındaki görüşlerinin değerlendirilmesi. IBAD Journal, 3(1), 131-144.

Tapscott, D. (2009). Grown up digital: how the net generation is changing your World. New York: McGrawHill.

Uyduran, M. (2018). Sını öğretmenlerinin bilişim teknolojilerini kullanım düzeylerinin farklı değişkenler açısından incelenmesi. (Yüksek Lisans Tezi). Gaziantep Üniversitesi Eğitim Bilimleri Enstitüsü, Gaziantep.

Vardar, T. (2015). İşyerinde farklı kuşakları yönetmenin yolu mentorluktan geçiyor. https://hbrturkiye.com/ blog/isyerinde-farkli-kusaklari-yonetmenin-yolu-mentorluktan-geciyor. Dowlanded at: 20.09.2020

Viera, A. J. \& Garrett, J. M. (2005). Understanding interobserver agreement: The kappa statistic. Family Medicine, 37(5), 360-363.

Wiedmer, T. (2015). Generations do differ: Best practices in leading traditionalists, boomers, and generations X, Y, and Z. Delta Kappa Gamma Bulletin, 82(1), 51.

Yıldırım, A. \& Şimşek, H. (2011). Sosyal bilimlerde nitel araştırma yöntemleri. (8. baskı). Ankara: Seçkin Yayıncılık.

Yu, H. C. \& Miller, P. (2005). Leadership style: The X Generation and Baby Boomers compared in different cultural contexts. Leadership \& Organization Development Journal, 26(1), 35-50.

Zemke, R., Raines, C., \& Filipczak, B. (1999). Generations at work: managing the clash of veterans, boomers, xers, and nexters in your workplace. First, Amacom: New York. 